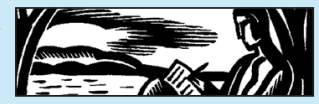

\title{
'Master Tommy Lucretius': Thomas Gray's Posthumous Life Writing and Conversing with the Dead in His Poetry to Richard West
}

\author{
James Morland \\ Queen Mary University of London
}

\section{ABSTRACT}

This article considers Thomas Gray's use of Lucretius' De Rerum Natura in his prolific period of writing following Richard West's death. Gray claims himself as 'Master Tommy Lucretius' in reference to his Latin philosophical poem, De Principiis Cogitandi; this self-presentation as a Lucretian poet continues through his English poetry concerning West's death. Gray's reference to conversing with the dead in a letter to West suggests that Gray's poetry concerning West can be considered a form of posthumous life writing in two specific senses: one as a continued memorializing West's life by Gray, and the other as a concurrent chronicling of Gray's grief. They reach their culmination when Gray puts his questioning of poetry as a form of memorial into action when using Lucretius' biography, and its associations with suicide, as a model of the suicidal poetic narrator in his Elegy Written in a Country Churchyard. The Elegy marks an end to Gray's use of Lucretius and De Rerum Natura to question the living's responsibility for continuing a posthumous memorial of the dead after West's death.

Keywords: Thomas Gray, Richard West, Lucretius, grief, memorial

You see, by what I sent you, that I converse, as usual with none but the dead: They are my old friends, and almost make me long to be with them. (Thomas Gray to Richard West, May 1742, Correspondence: 202)

This letter from Thomas Gray to Richard West is prophetic on many counts. Gray's poetry is often filled with allusions to multiple classical 
poets, presented here as conversations with 'old friends'. It was not long after this letter that West was also to become one of these old friends with whom Gray could only converse through poetry: he died in June 1742 , the month after this letter was sent. West's death had a profound effect on Gray and led to an extremely prolific period of writing, in which these conversations with dead poets continue with a specific resonance for Gray's grief. These conversations were integral to Gray's questioning of death, and one's continued life after another's death, in his composition of poetry after West's death. The poems written after West's death are distinctly biographical in their chronicling of Gray's grief and memorialise West and their relationship. Referencing life writing's dominant mode of defining oneself in relational terms, Sam Meekings notes that writing about loss brings this relationality to its logical end, highlighting 'that it is through our most important relationships that the textual self is both defined and produced' (Meekings: 414). Through these conversations with the dead and considering death in the context of the classical past alongside his own present loss, Gray defines his role as poet via his relationships with West and the classical poets. Gray acts as an intermediary between the living and the dead, preserving the life of the dead (both the classical poets and West) through poetry. In this article I posit that Gray engages in a form of posthumous life writing by presenting himself as poet, elegist, and mourner, and using poetry as a means of displaying his responsibility for the literary memorial (and continued literary life) of West. ${ }^{1}$ At the root of this is the paradox that to write of death and immortality, one must also write about life. The writing of death allows for a concurrent consideration of mortality and the meaning of being alive, and when one thinks and writes of death it is inherently linked to writing about one's own or another's current or past life. Gray's conversations with dead poets become an important means of memorialising both West's and his own life. Gray's poetry after West's death becomes a questioning of poetry as a form of posthumous life writing in the context of preserving one's legacy via elegy and memorial.

Gray's Elegy Written in a Country Churchyard (1751) was immensely popular on its initial publication, gaining five editions in its first year of publication, and has endured as one of the most canonical and oftenmemorised English poems. Memorial is key to Gray's Elegy which insists that the poor and humble have as much claim as the famous and great to live on in posterity. The Elegy presents Gray's thoughts on death and memorial in the context of society at large, but is deeply imbued with his personal sense of the loss of West. West's death lurks beneath the surface of the Elegy and Gray's poetic works produced directly after West's death inform the poem with what Katherine Turner terms 'personal allusion' 
(Turner, 'Elegy': 349). Gray's most explicitly mournful poem concerning West is the first poem Gray wrote following West's death in 1742, De Principiis Cogitandi. Not published until after Gray's death, the Latin poem is split into two parts: the first, presented as a purely philosophical poem on the principles of thinking with West as its muse, the second written directly following West's death which moves from philosophical reflection into a personal account of loss and grief.

By tracing the references to Lucretius, the famed author of De Rerum Natura who turned to poetry to document the atomistic processes of death and argue that it held nothing to fear, in these poems we can note how his 'conversations' with Lucretius shift from detailing the comings of spring to a philosophical questioning of death and the afterlife. By specifically looking at Gray's use of Lucretius, from the lamentations and solitary grief of De Principiis Cogitandi and 'Sonnet on the Death of Mr Richard West' to the narrator's implied suicide in the Elegy, we can see a process where Gray is conversing 'as usual, with none but the dead' on various different levels. Gray turns to Lucretius in his poetry after West's death, developing a conversation with the dead which includes both the classical poet and his recently deceased friend. We can trace how Gray uses Lucretius' voice and biography in these conversations with the dead, with De Rerum Natura becoming an intrinsic part of Gray's poetic chronicling of his grief and a posthumous memorial to West.

There is a distinct parallel between Gray's becoming 'Master Tommy Lucretius' when writing De Principiis Cogitandi and the Lucretian de-individualising approach to death and a suicidal poetic narrator in the Elegy. Through these Lucretian references, Gray's developing ideas of the living's responsibility to provide a memorial via a poetic form of posthumous life writing come to the fore. Gray questions the effectiveness of different material and textual concepts of memorial in alleviating grief in his poems after West's death, culminating in the questioning 'Can storied urn or animated bust / Back to its mansion call the fleeting breath?' (Gray, Elegy: 41-2) in the Elegy. His consideration of the living's responsibility for continuing the life of the dead similarly appears in the Elegy with reference to the 'frail memorial' (Gray, Elegy: 78) of a gravestone, which even with 'uncouth rhymes' and 'shapeless structure' provides some form of posterity and remembrance. While the focus in the Elegy is on the gravestone as a material memorial, the 'uncouth rhymes' featured on these gravestones speak to Gray's continued questioning of poetry as an adequate memorial for the dead across his poetry following West's death. While Gray considers the reliance of material and written memorial in the Elegy, the poems leading up to this questioning deal specifically with poetry's role in memorialization. The second and third lines of the 
first book of De Principiis Cogitandi (dedicated to West) note the tenuemque catenam / Mnemosyne [delicate chain of memory] (Gray, DPC: 2-3) and we should read his poems following West's death in the context of this chain, specifically poetry's close connections to memory and memorialization. From De Principiis Cogitandi, where Gray laments the loss of West and questions West's afterlife, to the Elegy, the poems written after West's death serve as a form of posthumous life writing in two distinct senses: one as a memorial of West's life via elegy and the other as a chronicling of Gray's own developing grief and understanding of death. These forms combine in Gray's presentation of poetry as a conversation with the dead to show how poetry becomes both a 'frail memorial' and a means to continue the life of the dead. The memorial poems culminate in the Elegy where these conversations with the dead conclude with Gray emphasising his own solitariness amongst the living, ultimately inhabiting a Lucretian persona to question his own poetic afterlife and apotheosis via an implied narratorial suicide. In that moment, Gray's longing to be with his 'old friends', is, poetically at least, complete.

There are two biographies that are significant for Gray's turn to death and the graveyard in his poetry post-West's death: Gray's own (specifically in relation to his grief for West) and the poetic persona of Lucretius. Lucretius' biography, and its associations with suicide, is significant to Gray's use of De Rerum Natura in his poetry after West's death, particularly in reference to the narrator's implied suicide in the Elegy. Whilst little detail is known about the actual circumstances of Lucretius' death, it is commonly conjectured that he committed suicide following the administration of a love potion by his wife. This was propagated heavily across the eighteenth century to signal the dangers of Lucretius' Epicurean philosophy. This connection of the figure of Lucretius and suicide further cemented following the suicide of the translator of the first full English translation of De Rerum Natura, Thomas Creech, in 1700. Creech's suicide brought about parallels between his death and the claims made about Lucretius' suicide by St. Jerome, with Epicureanism in general, and Lucretius' name explicitly becoming associated with suicide in anonymous pamphlets such as the A Step to Oxford (1700). ${ }^{2}$ In his work on eighteenth-century graveyard poetry, Eric Parisot has noted that De Rerum Natura was seen by some in the century as an apologia for suicide (Parisot: 131). For example, in another form of conversation with the dead, the references to suicide as 'a quick Relief / To all thy vain imaginary grief' (Dryden, 'Third Book': 88-9) from John Dryden's translation of De Rerum Natura are recited during the suicide of the husband in Letter VI of Elizabeth Singer Rowe's Friendship in Death: In Twenty Letters from the Dead to the Living: 
When he had finish'd and seal'd [his letter] he took a Lucretius from the Table, and read and paus'd by Intervals; at last looking on his Watch, just at Two he fasten'd his Chamber Door, and drew his Sword, repeating the following Lines, which I wish had never been writ, as I assure you does the Author of them too. [...] Then directing the Point exactly at his Heart, he fell on his Sword, and immediately expir'd [.] (Singer Rowe: 33) ${ }^{3}$

Lucretius' text was seen as approving and rationalizing suicide, and Creech's death was quickly linked to this influence. In a survey of suicide in Western culture, George Minois notes Voltaire's contribution to these myths of Creech's death, in his (conjectural) suggestion that Creech wrote within his Lucretian marginalia, 'N.B. Must hang myself when I am finished' (Minois: 179). Speculation on Creech's life and death became entwined with that of Lucretius, with their suicides becoming a means to advance criticism of the atomistic vision of death in Lucretius' philosophy and poetry. These connotations were also made clear in poetry as well as prose, with Lucretius and an atomistic view of creation and destruction being explicitly linked to suicide in Robert Blair's 1743 The Grave. Blair reworks the Lucretian cyclic system of atomistic destruction and creation that is central to his theory of life and death to form a circular society of immorality in the image of the drunkard who might:

Reel over his dull bowl, when 'tis drain'd

Fill up another to the brim, and laugh

At the poor bugbear Death (Blair: 187-9)

Blair alludes to Dryden's translation of the latter part of Book III of De Rerum Natura, the opening lines of which ask the reader: 'What has this Bugbear Death to frighten Man,/ If Souls can die, as well as Bodies can?' (Dryden, 'Third Book': 1-2). Blair's stanza suggests that this view of death would give 'the wretch / That's weary of the world' the excuse to '[steal] out of being when he pleas'd' (Blair: 389-92), before becoming a polemic against the act of suicide. ${ }^{4}$ The Lucretian cyclical system is interwoven with immorality and paralleled with the 'island's shame [suicide]' (Blair: 403). Lucretius as the poet of death and suicide was an association that Gray embraced in his grief-stricken poetry following West's death and one that his poetic persona would go on to replicate.

W. Hutchings has noted Gray's use of Latin as the 'most intimate form of communication with his most intimate friend' (Hutchings: 120). Through Latin, Gray could encode same-sex feelings into traditional classical tropes (Turner, 'Gray'). Gray's final Latin poem to West, the second part of his philosophical De Principiis Cogitandi, continues this intimate communication into the realm of death and contributes to a 
poetry concerned with ideas of memorial, death, and loss. Referring to the poem in a letter to Thomas Wharton in 1744, Gray names himself as 'Master Tommy Lucretius', embarking on a philosophical poetic venture which would produce the equivalent to Lucretius' extended poem De Rerum Natura, though with Lockean rather than Epicurean doctrines. ${ }^{5}$ The 'Master Tommy' moniker is interestingly juvenile, especially in contrast to the classical association with Lucretius. Gray uses the schoolboy persona in part to mock his own work as a philosophical poet, though the self-deprecating nature of his commentary should not distract from the importance of this association with Lucretius in this and later poems. Gray furthers the significance of the schoolboy moniker with reference to 'Master Tommy Lucretius' as having 'the Worms, that will carry it off at last'. The image of his Lucretian poet as a child allows Gray to draw a connection between the childhood ailment of worms and worms as memento mori via their devouring of corpses (Skuse: 644). Read in light of Lucretius as the poet of death who committed suicide, the guise of Tommy Lucretius is a memento mori in and of itself, inherently connected to philosophical considerations on the inevitability of death and also with the death of the poet. In this self-deprecation, Gray begins the process of killing off this Lucretian persona who will eventually be '[carried] off at last' in a suicide at the end of the Elegy. The second part of De Principiis Cogitandi was begun in Gray's Commonplace Book in June 1742, directly after West's death, and is most deeply connected to Gray's feelings of loss, memory and memento mori. It marks a distinction between 'Master Tommy Lucretius', who attempts to write philosophical poetry, and the 'Master Tommy Lucretius', sick with worms, who writes on death and its cycles and aftermaths and longs to be with the dead. Gray's Latin poem, with its emphasis on loss and West's death is a precursor to his discussions on the fear of death in his later Elegy, ultimately inhabiting the role set by Lucretius' and Creech's biographies: the suicidal poet.

\section{'MASTER TOMMY LUCRETIUS'}

William Mason introduces De Principiis Cogitandi in his 1775 Memoirs of Thomas Gray with an interpretation of its design, suggesting that Gray was aiming to create a Lockean philosophical poem in the manner of Lucretius' Epicurean De Rerum Natura: 'It is clear, however, from the Exordium itself, that he meant to make the same use of Mr. Locke's Essay on the Human Understanding, which Lucretius did of the Dogmas of Epicurus' (Mason: 158). As mentioned above, Gray saw his role as poet in this context as distinctly Lucretian, referring to himself as 'Master Tommy 
Lucretius' when discussing the poem with Wharton. While drafting the first book of the philosophical poem, Gray sent the first 53 lines to West in a letter dated 21 April 1741, in which Gray states that it is 'the beginning not of an epic Poem, but of a Metaphysic one. [...] Pray help me to the description of a mix mode, and a little episode about Space' (Gray, Correspondence: 183). At the beginning of the philosophical venture, and Gray's first uptake of a Lucretian persona, he calls on West to help him begin. He dedicates the Liber Primus 'Ad Favonium', 'to Favonius'; this was West's nickname amongst the Quadruple Alliance, the quartet of friends at Eton comprised of Thomas Gray, Richard West, Horace Walpole, and Thomas Ashton (Mack: 102-4).

The second part of the poem, written in the aftermath of West's death, takes a distinctly personal turn. Though not explicitly dedicated to West, it is perhaps even more 'Ad Favonium' than the Liber Primus. A marginal note to the transcript in Gray's Commonplace Book notes that it was 'Begun at Stoke, June, 1742', the same month as West's death (Lonsdale: 322). Writing to Horace Walpole in 1747, Gray sent the first 29 lines of Book II, stating that it "was intended to treat of the Passions. Excuse the 3 first Verses: you know Vanity (with the Romans) is a poetical License' (Gray, Correspondence: 267). This 'vanity' is Gray's move away from the philosophical to a personal reflection on West's death, with the elegiac lines becoming his first conversation with the dead in relation to West. He laments that West, 'the inspiration and cause of so great a task' has 'deserted me in the midst of it and [has] hidden [himself] in the eternal shadow of Death!' (Lonsdale: 332). West has become one of the 'old friends' referenced in his May 1742 letter, and the conversation has become one-sided:

Humanam si forte alta de sede procellam

Contemplere, metus stimulosque cupidinis acres,

Gaudiaque et gemitus, parvoque in corde tumultum

Irarum ingentum, et saevos sub pectore fluctus:

Respice, et has lacrimas, memori quad ictus amore

Fundo; quod possum, iuxta lugere sepulcrum

Dum iuvat, et mutae vana haec iactare favillae. (Gray, De Principiis Cogitandi: II: 23-9)

If, by chance, you look down from your lofty seat on the storm of the human passions, the fears, the fierce promptings of desire, the joys and sorrows and the tumult of rage so huge in our tiny hearts, the furious surges of the breast; then look back on the tears, also, which, stricken with love, I pour out in memory of you; this is all I can do, while my only wish is to mourn at your tomb and address these empty words to your silent ashes. (Lonsdale: 332) 
Gray is having multiple conversations with the dead in these lines. Here, Gray becomes a very different 'Master Tommy Lucretius', shifting from the philosophical poet questioning the nature of the universe to the philosophical poet questioning death, how best to create a memorial for West, and to document his own grief through poetry. The two become intertwined, with the memorial for West intrinsically linked to his poetic description of his own tears. Gray then turns to another classical poet, Catullus, to help formulate his first poetic conversation with West after his death:

I come, my brother, to these sorrowful obsequies, to present you with the last guerdon of death, and speak, though in vain, to your silent ashes, since fortune has taken your own self away from me [...] a sorrowful tribute-for a funeral sacrifice; take them, wet with many tears of a brother, and for ever, O my brother, hail and farewell! (Catullus: 173)

With Catullus as his elegiac precedent, Gray uses his elegy to question the use of poetry as a memorial to West. Whilst Catullus focuses on the sorrow of the brother through the repeated use of frater throughout the elegy, Gray instead uses his elegy to emphasise the connection between love, tears, and memory. The construction of et has lacrimas, memori in line 27 intimately connects his tears with West's memory, a connection which will reappear in his English sonnet to West. Gray turns to the philosophical poem which had West as its 'inspiration and cause' as his first attempt at assuming his responsibility for West's continued memorial, lamenting that writing of his tears 'is all I can do', whilst turning to his trusted conversations with dead classical poets to create a memorial to the newly deceased West.

There is also a conversation with Lucretius within this Catullus-inspired elegy. Gray marks in the margins of his Commonplace Book that, 'if, by chance, you look down from your lofty seat on the storm of the human passions' alludes to 'the storm of the soul' in Epicurus' letter to Menoeceus: 'For we do everything for the sake of being neither in pain nor in terror. As soon as we achieve this state every storm in the soul is dispelled' (Epicurus: 30). From this reference we can ascertain that Gray turned to Epicurus' letter to Menoeceus, in which Epicurus recounts his central idea that 'death is nothing to us', in the aftermath of West's death. Gray takes up the mantle of Lucretius here to create a poetic exposition of Epicureanism in the face of death. Though instead of a purely detached and Lucretian view of death, Gray reflects on the personal effects of West's death. Unlike Lucretius, who uses Epicureanism to remove the fear of death and question extended periods of grief, Gray's grief is amplified by his turn to Epicureanism. West's life, leading him to this 'lofty seat on the 
storm of human passion', has allowed him to achieve the Epicurean ideal of being neither in pain nor terror. In this poetic conversation with the dead, Gray turns to both Epicurus and West to present West's life (and death) as the ideal in this memorial. To memorialise is double-edged for Gray, reminding him of his own personal loss and solitariness in the face of the death of his friend, who is now a 'blessed spirit' and 'released from cares' (Gray, DPC: II 18-20). Poetry becomes a means to remember the dead's ideal life and to chronicle the solitary life of those left behind. He is troubled that West is 'now beyond mortal concerns', and cannot remember him. Poetry allows Gray to document his grief for West and to recount his 'tears, also, which, stricken with love, I pour out in memory of you'. In this poem, West's death is at its closest and most visceral, with the second part of the philosophical poem becoming a personal invocation of his passion for West and a chronicling of his grief as a time 'spent in mourning, which I am forced to pass without you, in weeping because you are not there, and in vain complaints' (Lonsdale: 332). This mourning is to continue across Gray's poetry, but the distance from death is key to understanding how Gray is using his poetry to document his processing of West's death. As time passes, his narratorial distance from death becomes greater as he turns to Lucretius more explicitly when discussing death. Through his continued poetic conversing with Lucretius, Gray simultaneously memorialises West's life and documents his own life of grief until he fully embraces the Lucretian poetic persona as a means to join West in the 'eternal shadow of Death'.

\section{THE CYCLES OF SPRING AND GRIEF}

To understand the significance of Gray's reliance on Lucretius in describing death in his English poetry after West's death, we should first turn to Gray's last poem to West before his death. Gray notes in his Commonplace Book that his 'Noon-Tide, An Ode' was written 'at Stoke, the beginning of June, 1742. Sent to Fav [Favonius]: not knowing he was then Dead' (Lonsdale: 48). In this poem, Gray's first to West in English, Gray turns to Lucretius to provide the imagery of Venus and the vernal growth of spring:

Lo! Where the rosy-bosomed Hours,

Fair Venus' train, appear,

$[\ldots]$

While whispering pleasure as they fly,

Cool zephyrs through the clear blue sky

Their gathered fragrance fling. (Lonsdale: 48-9) 
On come Spring and Venus, and Venus' winged harbinger marching before, with Zephyr and mother Flora a pace behind him strewing the whole path in front and filling it with brilliant colours and scents. (Lucretius: V.737-40)

Gray's conversing with Lucretius here is associated with spring's fragrant burgeoning of life. Lucretius' poem is one of many that Gray uses to echo the classical tradition of the retired poet invoking spring and contemplating society from a distance. The poem ends with Gray considering himself as a 'solitary fly', and documenting that nothing, including himself and the burgeoning spring, lasts forever: 'Thy sun is set, thy spring is gone-/ We frolic, while 'tis May' (Gray, 'Spring': 49-50). This ending is particularly Lucretian in tone, invoking Lucretius' larger argument that these cycles of life and death in the seasons are 'a mirror which nature holds up to us, showing the time to come after we at length shall die' (Lucretius: III. 974-5). Lucretius then questions 'Is there anything horrible in that? Is there anything gloomy?' (Lucretius: III. 976-7). Gray does not fully answer these questions, instead mocking his own moralising poetic image as the 'solitary fly' who fritters away his youth, but does suggest that the inevitable end to May (and life) leads to a fuller enjoyment of its frolicking. Gray minds these questions throughout his poetry, and his answers and the connotations of his use of Lucretius change significantly in the face of West's death and his subsequent grief.

Gray returns to Lucretius' invocation of a thriving nature in the opening lines of his 'Sonnet on the Death of Mr Richard West', but places the renewal of spring in direct contrast with his own cycles of grief:

In vain to me the smiling mornings shine,

And reddening Phoebus lifts his golden fire:

$[\ldots]$

My lonely anguish melts no heart but mine;

And in my breast the imperfect joys expire. (Gray, Sonnet: 1-8)

Again, when nature begins to uplift on high the sun's beam red with flickering fires (Lucretius: IV.404)

Whilst Gray's solitude is the central focus of both the ode and sonnet, Gray's grief in the sonnet leads this solitariness to be one of endless cycles of sorrow, highlighted by the repetition of 'in vain' at the beginning and very end of the poem. In contrast to nature which continues to bloom in its continual cycles, his 'lonely anguish' causes a stagnation where his 'imperfect joys' continually expire. Gray's use of Lucretius, whose De Rerum Natura notes the continual atomistic cycles of destruction and rebirth in 
nature to allay the fear of death, is intimately connected to his poetic presentation of his cycles of grief. Invoking Lucretius' uplifting reddening skies at the beginning of the poem through his reference to 'reddening Phoebus' lifting 'his golden fire', Gray leans on a classical precedent for his own poetic dealings with death, providing a parallel between his own grief and the continual cycles of nature's rebirth. His use of Lucretius' generative spring becomes a means of chronicling his grief in the direct aftermath of West's death, in contrast to the contemplative exploration of the 'hasty wings' of youth in 'Ode on the Spring'. Read as a pair, these poems present a distinct change in tone in Gray's use of Lucretius: his use of De Rerum Natura shifts from a classical precedent of viewing the cycles of life and death from a distance to a means of exposing the personal 'lonely anguish' of grief. Lucretius once again provides Gray with a poetic precedent for exploring death, though here his personal grief takes over. To return to Lucretius' questions, death is now gloomy and horrible for Gray. As in De Principiis Cogitandi, Gray ends the sonnet with a lament on the loss of West: 'I fruitless mourn to him that cannot hear, / And weep the more because I weep in vain' (Gray, 'Sonnet': 13-14). Just as Epicurus' Letter to Menoeceus could not provide comfort for Gray in his Lucretian Latin guise, here the Lucretian cycles do not provide comfort but become a means of documenting grief. Gray evokes Lucretius in these moments of grief, using De Rerum Natura's known associations with cyclical systems to chronicle his own developing grief. This grief is all consuming in this early exploration, but Gray will continue his conversations with Lucretius throughout his poetry to provide a means of documenting his changing grief and concepts of memorial, slowly adopting a more Lucretian approach to death.

\section{JOINING WEST IN THE 'ETERNAL SHADOW OF DEATH'}

As Joseph Foladare comments, the Elegy completes Gray's memorial to West (Foladare: 65). The mourning poet's autobiography has been noted as an active subtext of the elegiac form (Shaw; Smythe: 6-8), and Gray's Elegy is infused with his own grief. While the Elegy has most often been read in reference to its more general concerns of death and memory, the personal elements of grief that run beneath the surface of the poem add to its poignancy, especially in the context of Gray's lines on inevitable death. As Turner points out, while the reader of 1751 would not have known the personal allusions that run throughout the poem, they contribute to the poem in an 'indefinable way' (Turner, 'Elegy': 349). The Elegy marks the culmination of Gray's poetic considerations of memorial and his conversations with Lucretius, and presents a philosophical 
consideration of death and remembrance where Gray enacts his guise of 'Master Tommy Lucretius' to its fullest. Gray moves from the sounds of the churchyard to the lack of senses of the dead, turning to a Lucretian example of the loss of earthly experience after death:

For them no more the blazing hearth shall burn,

Or busy housewife ply her evening care:

No children run to lisp their sire's return,

Or climb his knees the envied kiss to share. (Gray, Elegy: 21-4)

No longer now will your happy home give you welcome, no longer will your best wives; no longer will your sweet children race to win the first kisses, and thrill your heart to its depths with sweetness (Lucretius: III. 894-6)

Gray uses this Lucretian imagery at the turning point of his poem. Many critics have noted Gray's use of this image in his sixth stanza, though it can be taken further to suggest that Lucretius' 'darker undercurrent', as termed by Henry Weinfield, is also evident on the surface of the fourth and fifth stanza. ${ }^{6}$ This undercurrent moves the poem away from the 'drowsy tinklings' of the pastoral scene to the finality of death, and represents a key moment in Gray's shift towards a more detached and philosophical consideration of death and remembrance. Following Lucretius' example, he moves readers from their present sensory experience to contemplate the loss of these, for example the warmth of the 'blazing hearth' or the 'evening care' of a wife, after death. At this turning point, Gray becomes the mediator of the nighttime of the living and the 'eternal shadow of Death' that provoked such discomfort in De Principiis Cogitandi. His distanced perspective from death is made larger in this shift, itself exemplified by another Lucretian appropriation:

Far from the madding crowd's ignoble strife,

Their sober wishes never learned to stray;

Along the cool sequestered vale of life

They kept the noiseless tenor of their way. (Gray, Elegy: 73-6)

But nothing is more delightful than to possess lofty sanctuaries serene, well fortified by the teachings of the wise, whence you may look down upon others and behold them all astray, wandering abroad and seeking the path of life:- the strife of wits, the fight for precedence [...] O pitiable minds of men, O blind intelligences! In what gloom of life, in how great perils is passed all your poor span of time! (Lucretius: II.6-16) 
The image of the crowd's passage through the 'vale of life' leads the reader to contemplate their own life and mortality from this distanced philosophical viewpoint. The rhymed 'ignoble strife' and 'vale of life' follow the same bleak parallel of the 'path of life' and the 'strife of wits' in De Rerum Natura. Gray's perspective follows a Lucretian detached view of death, using a distanced perspective to comment on the larger system of life in contrast to the specific focus on individuals earlier in the poem (and later in the poem's epitaph) and his own focus on his individual response to the death of West in his previous poetry. From this detached perspective, the narrator leads the reader to contemplate the 'ignoble strife' of the dead, again using Lucretius' poetic imagery to detach from the present and view a more general un-sensing world of the dead from the heights of philosophical contemplation. Gray creates a poetic space for the narrator to be reminded, and to remind the reader, that all are ultimately moving towards the same inevitable end (Fulford: 118). While this end may be inevitable, Gray also makes clear that memorial is needed.

Gray follows his Lucretian stanza documenting the 'crowd's ignoble strife' with a reminder to the reader of the need for tribute:

Yet even these bones from insult to protect

Some frail memorial still erected nigh,

With uncouth rhymes and shapeless sculpture decked,

Implores the passing tribute of a sigh. (Gray, Elegy: 76-80)

As we have seen in Gray's works after West's death, poetry, even in 'uncouth rhymes', is a means of remembrance, if only just a 'frail memorial'. Two stanzas later, Gray returns to Lucretius again when documenting the dead's leaving of 'the warm precincts of the cheerful day' (Gray, Elegy: 87), infusing his own philosophising on death and memorial with Lucretius' 'they left the sweet light of lapsing life' (DRN: V. 989) (Lonsdale: 133n). In this rendition of inevitable death, Gray then suggests that 'On some fond breast the parting soul relies, / Some pious drops the closing eye requires' (Gray, Elegy: 89-90), producing a form of redemption that is intrinsically linked to sympathy and a posthumous remembrance. Throughout this consideration of remembrance, he echoes his previous poetry concerned with the death of West and introduces some conclusions to his questioning of the afterlife of the individual and remembrance from De Principiis Cogitandi by enacting the disappearance of his own narrator within the poem itself.

Just as he has done for West, Gray tries to take control of the future memorial of the poet by calling on the reader to provide a form of poetic afterlife for his narrator. The poem ends as a form of posthumous life 
writing of the narrator, with the 'hoary-headed swain' (Gray, Elegy: 97) recounting and remembering his life. It is notable that Gray turns to Lucretius most explicitly in the poem just before the narrator's disappearance. In light of this disappearance, Parisot re-reads the poem's memento mori, 'The paths of glory lead but to the grave' (Gray, Elegy: 36), as an inference toward the narrator's suicide as an avenue to wisdom and apotheosis (Parisot: 133). Only delving into the act of death itself will lead Gray's narrator to poetic glory. Gray becomes 'Master Tommy Lucretius' most fully here, contemplating the inevitability of death before, like Lucretius himself, the narrator ends his own life. As noted above, Lucretius' suicide led to a consistent retelling of the poet's biography throughout the eighteenth century, a certain type of (not wholly positive) memorial. Gray's turn to Lucretius mimics this within the form of the poem itself, with the narrator's implied suicide leading to a form of memorial via a recounting of his life and reading of his epitaph by the 'kindred spirit' of the reader. The conversation with Lucretius allows Gray to fully expand on his own desire for a personal and individual remembrance, which in part stems from his memorialising of West. At the moment of the narrator's implied death, the various strands of posthumous memorial in Gray's poetry about West converge. Gray's chronicling of his own grief via Lucretius culminates in a poetic acceptance of death with an addendum of his desire for a memorial, whilst the swain takes up the mantle of the memorial poet set by Gray in his own poetry about West, continuing the memory of the narrator via a poetic form of posthumous life writing.

The continual cycles of tears that punctuate his poetry on West become a part of Gray's moralising attempts to consider remembrance through 'pious drops'. Karen Smythe notes that life-writing serves a fundamental purpose in elegy writing, with autobiography distancing 'the speaker from the scene of death and [reminding] the reader that life does indeed go on' (Smythe: 7). Gray, instead, uses the distance to focus on remembrance and memorial. The section of the Elegy most explicitly dealing with memorial is also Gray's reflection on his chronicling of grief and memorialising of West, looking back to his previous poetry where he 'fruitless mourn[s] to him that cannot hear, / And weep the more because I weep in vain' (Gray, 'Sonnet': 13-14). When read in succession, these poems question how the living can best take responsibility for the writing of the lives of the dead. The chronicling of grief throughout his poetry leads Gray to this moment of detaching himself from the process of death and allows a tracing of Gray's personal narrative of grief within this quest for remembrance. Lucretius' poetry is the constant undercurrent through Gray's poetry of lament, but comes to the fore in the Elegy where Gray combines his own poetic biography with that of Lucretius by 
becoming the poet of death who brings about his own death. The Elegy brings Gray full circle, becoming the poet, elegist, mourner, and the dead himself. It enacts Gray's questioning of the continued life of the deceased through writing. To return to the May 1742 letter to West, this death of the narrator is perhaps the inevitable result of a longing to be with his 'old friends' with whom he has been conversing throughout his works and a chance to (poetically) join West in the 'eternal shadow of Death'.

\section{WORKS CITED}

Bennett, Andrew. Keats, Narrative and Audience: The Posthumous Life of Writing. Cambridge: Cambridge University Press, 1994.

Blair, Robert. The Grave: A Poem (1743), Augustan Reprint Society. Vol. 161. Los Angeles: William Andrews Clark Memorial Library, University of California, 1973.

Butterfield, David. 'Lucretius in the Early Modern Period.' In: David Norbrook, Stephen Harrison and Philip Hardie (eds.), Lucretius and the Early Modern. Oxford: Oxford University Press, 2015.

Cornish, F. W. Catullus, Tibullus and Pervigilium Veneris. Trans. J. P. Postgate and J. W. Mackail. Cambridge, MA: Harvard University Press, 1913.

Dryden, John. 'Third Book of Lucretius.' In: Sylvae: Or, the Second Part of Poetical Miscellanies. London: Printed for Jacob Tonson, at the Judges-Head in Chancery-Lane near Fleetstreet, 1685 .

Epicurus. The Epicurus Reader: Selected Writings and Testimonia. Trans. Brad Inwood and L. P. Gerson. Indianapolis: Hackett, 1994.

Foladare, John. 'Gray's "Frail Memorial” to West.' PMLA 75:1 (March, 1960) 61-65. DOI: https://doi.org/10.2307/460427.

Fulford, Tim. 'Nature” Poetry.' In: John Sitter (ed.), The Cambridge Companion to EighteenthCentury Poetry. Cambridge: Cambridge University Press, 2001, 109-132. DOI: https://doi. org/10.1017/CCOL0521650909.006.

Gray, Thomas. The Correspondence of Thomas Gray: Vol I. In: Paget Toynbee and Leonard Whibley (eds.). Oxford: Clarendon Press, 1935.

Hopkins, David. Conversing with Antiquity: English Poets and the Classics, from Shakespeare to Pope. Oxford: Oxford University Press, 2009.

Hutchings, W. 'Conversations with a Shadow: Thomas Gray's Latin Poems to Richard West.' Studies in Philology 92:1 (Winter, 1995) 118-139.

Lonsdale, Roger (ed.). The Poems of Gray, Collins and Goldsmith. London: Longman, 1969.

Lucretius. De Rerum Natura. Trans. W. H. Rouse. Cambridge, MA: Harvard University Press, 1992.

Mack, Maynard. Thomas Gray: A Life. New Haven: Yale University Press, 2000.

Mason, William (ed.). The Poems of Mr. Gray. To which are Prefixed Memoirs of His Life and Writings by W. Mason, M.A. York: printed by A. Ward; and sold by J. Dodsley, London; and J. Todd, York, 1775.

Meekings, Sam. 'Writing through Loss: The Rise of Grief Narratives through the Lens of Libville's Self-complexity Theory.' Life Writing 16:3 (2019) 413-427, DOI: https://doi.org /10.1080/14484528.2018.1537048.

Minois, George. History of Suicide: Voluntary Death in Western Culture. Baltimore: Johns Hopkins Press, 1999. 
Parisot, Eric. Graveyard Poetry: Religion, Aesthetics and the Mid-Eighteenth-Century Poetic Condition. Surrey: Ashgate, 2013.

Shaw, W. D. 'Elegies.' In: M. Jolly (ed.), Encyclopedia of Life Writing: Autobiographical and Biographical Forms. Abingdon, Oxford: Routledge, 2001.

Skuse, Alanna. 'Wombs, Worms and Wolves: Constructing Cancer in Early Modern England.' Social History of Medicine 27:4 (November, 2014) 632-648.

Singer Rowe, Elizabeth. Friendship in Death: In Twenty Letters from the Dead to the Living. London: Printed for T. Worrall, at the Judge's-Head, over against St. Dunstan's Church, 1722.

Smythe, Karen E. Figuring Grief: Gallant, Munro, and the Poetics of Elegy. Montreal: McGillQueen's University Press, 1992.

Turner, Katherine. 'Thomas Gray, Elegy Written in a Country Churchyard.' In: David Womersley (ed.), A Companion to Literature from Milton to Blake. Oxford: Blackwell, 2000, 345-352.

Turner, Katherine. 'Thomas Gray.' Oxford Handbook Online (November 2015). Oxford University Press, http://www.oxfordhandbooks.com/view/10.1093/oxfordhb/9780199935338.001.0001/oxfordhb-9780199935338-e-123, DOI: https://doi. org/10.1093/oxfordhb/9780199935338.013.123. Date accessed: 29 April 2019.

Weinfield, Henry. The Poet without a Name: Gray's Elegy and the Problem of History. Carbondale, IL: Southern Illinois University Press, 1991.

\section{ABOUT THE AUTHOR}

James Morland is a postdoctoral research fellow at Queen Mary University of London. He specializes in eighteenth-century literature with a specific interest in poetry and its intersections with philosophy and medicine, including the relationship between materialism and poetic rhythms and poetry as a means of exploring death and grief. At Queen Mary he is a part of the Wellcome-funded 'Pathologies of Solitude, $18^{\text {th }}-21^{\text {st }}$ Century' project $(207863 / \mathrm{Z} / 17 / \mathrm{Z})$, where he is working on a monograph considering solitude in relation to contemplations of life and death in various poetic contexts across the eighteenth century. E-mail:j.morland@qmul.ac.uk.

\section{NOTES}

1 This concept of 'posthumous life writing' is informed by Andrew Bennett's consideration of writing and reading as involving 'a kind of "posthumous life"' in relation to the Romantic notion of 'posterity', with writing becoming a 'posthumous supplement of a life' for an author. Though I am particularly interested in how Gray uses this concept in relation to others (namely West) as well as himself as author. Bennett (9-10).

2 Butterfield references the anonymous pamphlet, A Step to Oxford, published in 1700, noting the slandering of Creech as 'the famous Translator of Lucretius' filled with 'GoatishEye' of lust in the pulpit. (60).

3 Quoted in Parisot (131).

4 'Self-murder! Name it not; our island's shame; [...] Forbid it Heaven!'. Blair, The Grave (403-7).

5 'Master Tommy Lucretius (since you are so good to enquire after the Child) is but a pulsing chitt yet, not a bit grown to speak off, I believe, poor Thing! it has got the Worms, that will carry it off at last'. Thomas Gray to Thomas Wharton, 26 April 1744. In: Correspondence (244).

6 See, Lonsdale (121n); Hopkins (104); Weinfield (55). 